\title{
CORRELATION BETWEEN THE LEVEL OF COLORECTAL ANASTOMOSIS AND ANORECTAL FUNCTION
}

\author{
Branko Bakula ${ }^{1}, \check{Z}_{\text {arko Rašićí1,4 }}$, Dragan Jurčićí, \\ Marko Lucijanić 3 and Fran Rašić ${ }^{4}$
}

\author{
${ }^{1}$ Department of Abdominal Surgery, Sveti Duh University Hospital, Zagreb, Croatia; \\ ${ }^{2}$ Department of Gastroenterology, Sveti Duh University Hospital, Zagreb, Croatia; \\ ${ }^{3}$ Department of Hematology, Dubrava University Hospital, Zagreb, Croatia; \\ ${ }^{4}$ School of Medicine, University of Zagreb, Zagreb, Croatia; \\ ${ }^{5}$ Faculty of Medicine, Josip Juraj Strossmayer University of Osijek, Osijek, Croatia
}

\begin{abstract}
SUMMARY - Anterior rectal resection is a standard surgical procedure for treating carcinomas of rectum and distal sigmoid colon. In many cases of anterior rectal resection, postoperatively some level of fecal incontinence may occur. The aim of our study was to evaluate the impact of the colorectal anastomosis level on anorectal functional disorder. In our prospective study, the participants were patients diagnosed with carcinoma of rectum or distal sigmoid colon. All patients underwent standard open or laparoscopic anterior rectal resection. Six months after the surgery, the function of anorectum was evaluated in all participants. Finally, 38 patients were analyzed, including $13 / 38(34.2 \%)$ patients with high rectal anastomosis, 11/38 (28.9\%) with mid rectal anastomosis and 14/38 (36.8\%) with low rectal anastomosis. Patients with a lower level of anastomosis had a statistically significantly greater number of stools, higher urgency and discrimination impairment, more pronounced solid, liquid and gas incontinence, and greater need for diapers ( $\mathrm{p}<0.05$ all). Therefore, patients with lower anastomosis had a statistically significant impairment of their quality of life and higher Wexner score $(\mathrm{p}<0.001$ for both analyses). Our study results suggested reduced neorectal capacity to be the main pathophysiological factor for the development of postoperative anorectal function impairment.
\end{abstract}

Key words: Anterior resection; Rectal cancer; Wexner incontinence score; Anorectal function

\section{Introduction}

Colorectal carcinoma is the third most common malignant tumor in men and second most common in women $^{1-4}$. One third of all colorectal carcinomas are located in the rectum ${ }^{5,6}$. Anterior rectal resection is a standard surgical procedure for treating carcinomas of the rectum and distal sigmoid colon. It includes resection of part of or the whole rectum and part of the

Correspondence to: Branko Bakula, $M D$, Department of Abdominal Surgery, Sveti Duh University Hospital, Sveti Duh 64, HR10000 Zagreb, Croatia

Email: bakulabranko@gmail.com

Received December 4, 2018, accepted May 27, 2019 sigmoid colon while establishing intestinal continuity by creating colorectal or coloanal anastomosis.

Ever since the $4^{\text {th }}$ decade of the last century, when Claude Dixon described and popularized this operation, complications such as postoperative incontinence have been observed ${ }^{7}$. In the early 1990s, new surgicaloncologic consensus was brought about a safe distal resection margin on the rectum of only $1 \mathrm{~cm}$ compared to the previous $5-\mathrm{cm}$ margin. This greatly increased the rate of rectal cancers treated by anterior resection ${ }^{8}$. Many carcinomas of the middle and distal third of the rectum, which previously would have been treated with a much more radical operation such as abdominoperineal rectal amputation, then began being treated 
with low anterior resection. All of that led to actualization of the postoperative anorectal dysfunction problems. In fact, the problem became so common that a new term, "anterior resection syndrome", was introduced in medical literature?.

Anterior resection syndrome includes the following:

- fecal incontinence (measured by various scoring systems, of which one of the most commonly used is Wexner incontinence score $)^{10}$;

- urgency (inability to postpone defecation for longer than 15 minutes after the first sense of urge);

- stool discrimination disorder (inability to recognize the type of stool before defecation); and

- increased number of daily stools (frequency).

The pathophysiological mechanism of anorectal dysfunction after anterior rectal resection is still not completely clear. Decreased capacity of the neorectum, damage to anorectal innervation during rectal dissection and mechanical lesion of the anal sphincter are considered as the most probable causes ${ }^{11-14}$.

According to the location of colorectal anastomosis, anterior rectal resections are divided into low and high resections. However, exact distinction between these two groups is not clearly defined. Still, among surgeons, resections where anastomosis is created on the extraperitoneal part of the rectum are commonly referred to as low anterior resections.

The length of the rectum varies individually from 15 to $20 \mathrm{~cm}$. Surgical rectum is considered to begin distally on the upper border of the puborectal muscle with gradual transitions to the sigmoid colon containing haustra coli and epiploic appendices. It is common among surgeons and anatomists to divide the rectum into three parts according to the absolute distance from the anal verge $(<7 \mathrm{~cm}, 7-12 \mathrm{~cm}$ and $>12 \mathrm{~cm})$ or according to the relationship with the peritoneum (peritoneal reflection) ${ }^{15}$. Parietal peritoneum approaches different sides of the rectal wall at different levels. Looking from distally to proximally, the peritoneum first approaches the rectum on the anterior wall and after that it approaches on the lateral walls and the posterior wall. Taking that into account, the extraperitoneal part of the rectum is considered to be distal third of the rectum (part of the rectum below the rectovesical/rectouterine excavation), the retroperitoneal part of the rectum is middle third (only the anterior side of the rectum is covered with peritoneum), and the intraperitoneal part of the rectum is considered to be proximal third of the rectum (anterior and both lateral walls of the rectum are covered with peritoneum) $)^{16-20}$.

The level of colorectal anastomosis depends on tumor location. Respecting the current surgical oncologic standards, patients with carcinomas of the middle or lower third of the rectum should be treated with low anterior resection including total mesorectal excision (TME), assuring a macroscopically clear distal margin of at least $1 \mathrm{~cm}$. Patients with carcinomas of the distal sigmoid colon or proximal third of the rectum can be treated with high anterior resection and partial mesorectal excision (PME), but they require a distal resection margin of at least $5 \mathrm{~cm}$ from the lower end of the tumor ${ }^{21-24}$.

When searching medical literature, clear worsening of anorectal function with decrease in the colorectal anastomosis level in the low anterior rectal resections is observed. On the other hand, results of studies with high resections are scarce and have varying results ${ }^{25-29}$.

The aim of our study was to evaluate the impact of the colorectal anastomosis level on anorectal functional disorder.

\section{Patients and Methods}

We conducted this prospective study in patients hospitalized at Department of Surgery, Sveti Duh University Hospital, in whom anterior rectal resection was indicated due to colonoscopically and histologically diagnosed carcinoma of the rectum or distal sigmoid colon in the period between January 2016 and December 2017. Preoperatively, fecal continence status was evaluated in all patients using Wexner incontinence score. Patients with pre-existing fecal continence disorder (Wexner score $>0$ ) were not included in this study. Also, patients with prior rectal surgeries, dementia or other psychiatric disorders that would prevent the patient from answering the questionnaires were not candidates for our study. Exclusion criteria included major postoperative complications (e.g., anastomosis dehiscence, postoperative abscess or hemorrhage), loss to follow up or death within six months of operation.

All patients underwent a standard open or laparoscopic anterior rectal resection procedure in respect to all of the above-mentioned oncologic principles in- 


\section{Table 1. List of participants and their parameters}

\begin{tabular}{|c|c|c|c|c|c|c|c|c|c|c|}
\hline \multirow{2}{*}{$\begin{array}{l}\text { Patient } \\
\text { no. }\end{array}$} & \multirow{2}{*}{$\begin{array}{l}\text { Level of } \\
\text { colorectal } \\
\text { anastomosis }\end{array}$} & \multirow{2}{*}{$\begin{array}{l}\text { Number } \\
\text { of daily } \\
\text { stools }\end{array}$} & \multirow[b]{2}{*}{ Urgency } & \multirow{2}{*}{\begin{tabular}{|l} 
Fecal \\
discrimination \\
disorder
\end{tabular}} & \multicolumn{3}{|c|}{ Incontinence for: $(0-4)^{*}$} & \multirow{2}{*}{$\begin{array}{l}\text { Need } \\
\text { for pads } \\
(0-4)\end{array}$} & \multirow{2}{*}{$\begin{array}{l}\text { QOL } \\
\text { impairment } \dagger \\
(0-4)\end{array}$} & \multirow{2}{*}{$\begin{array}{l}\text { Wexner } \\
\text { scoreł } \\
(0-20)\end{array}$} \\
\hline & & & & & \begin{tabular}{|l|}
$\begin{array}{l}\text { Solid } \\
\text { stool }\end{array}$ \\
\end{tabular} & $\begin{array}{l}\text { Liquid } \\
\text { stool }\end{array}$ & Gas & & & \\
\hline 1 & \multirow{14}{*}{$\begin{array}{l}\text { Low } \\
\text { anastomosis }\end{array}$} & 5 & Yes & Yes & 0 & 1 & 0 & 1 & 2 & 4 \\
\hline 2 & & 5 & Yes & Yes & 2 & 2 & 2 & 2 & 3 & 11 \\
\hline 3 & & 4 & Yes & Yes & 1 & 2 & 2 & 1 & 3 & 9 \\
\hline 4 & & 2 & No & Yes & 0 & 1 & 2 & 0 & 3 & 6 \\
\hline 5 & & 3 & Yes & Yes & 1 & 2 & 2 & 0 & 2 & 7 \\
\hline 6 & & 2 & No & No & 0 & 0 & 3 & 0 & 2 & 5 \\
\hline 7 & & 1 & No & No & 0 & 0 & 0 & 0 & 0 & 0 \\
\hline 8 & & 6 & Yes & Yes & 2 & 3 & 3 & 3 & 4 & 15 \\
\hline 9 & & 3 & No & No & 0 & 0 & 1 & 0 & 1 & 2 \\
\hline 10 & & 3 & Yes & Yes & 2 & 2 & 2 & 0 & 1 & 7 \\
\hline 11 & & 4 & Yes & No & 0 & 1 & 2 & 0 & 2 & 5 \\
\hline 12 & & 3 & Yes & No & 0 & 1 & 1 & 0 & 2 & 4 \\
\hline 13 & & 2 & No & No & 0 & 0 & 1 & 0 & 1 & 2 \\
\hline 14 & & 1 & No & No & 0 & 0 & 0 & 0 & 0 & 0 \\
\hline 15 & \multirow{11}{*}{$\begin{array}{l}\text { Mid } \\
\text { anastomosis }\end{array}$} & 4 & Yes & Yes & 3 & 2 & 2 & 1 & 3 & 11 \\
\hline 16 & & 2 & Yes & Yes & 0 & 0 & 0 & 0 & 1 & 1 \\
\hline 17 & & 3 & No & No & 0 & 1 & 1 & 1 & 1 & 4 \\
\hline 18 & & 1 & No & No & 0 & 0 & 0 & 0 & 0 & 0 \\
\hline 19 & & 3 & Yes & No & 0 & 1 & 1 & 0 & 1 & 3 \\
\hline 20 & & 2 & No & No & 0 & 0 & 0 & 0 & 0 & 0 \\
\hline 21 & & 1 & No & No & 0 & 0 & 0 & 0 & 0 & 0 \\
\hline 22 & & 1 & No & No & 0 & 0 & 0 & 0 & 0 & 0 \\
\hline 23 & & 2 & No & Yes & 0 & 0 & 1 & 0 & 2 & 3 \\
\hline 24 & & 2 & No & No & 0 & 0 & 0 & 0 & 0 & 0 \\
\hline 25 & & 1 & No & No & 0 & 0 & 0 & 0 & 0 & 0 \\
\hline 26 & \multirow{13}{*}{$\begin{array}{l}\text { High } \\
\text { anastomosis }\end{array}$} & 1 & No & No & 0 & 0 & 0 & 0 & 0 & 0 \\
\hline 27 & & 2.5 & No & No & 0 & 0 & 0 & 0 & 1 & 1 \\
\hline 28 & & 1 & No & No & 0 & 0 & 0 & 0 & 0 & 0 \\
\hline 29 & & 0.5 & No & No & 0 & 0 & 0 & 0 & 0 & 0 \\
\hline 30 & & 0.5 & No & No & 0 & 0 & 0 & 0 & 1 & 1 \\
\hline 31 & & 1 & No & No & 0 & 0 & 0 & 0 & 0 & 0 \\
\hline 32 & & 1 & No & No & 0 & 0 & 0 & 0 & 0 & 0 \\
\hline 33 & & 1 & No & No & 0 & 0 & 0 & 0 & 0 & 0 \\
\hline 34 & & 1 & Yes & No & 0 & 0 & 0 & 0 & 1 & 1 \\
\hline 35 & & 1 & No & No & 0 & 0 & 0 & 0 & 0 & 0 \\
\hline 36 & & 1 & No & No & 0 & 0 & 0 & 0 & 0 & 0 \\
\hline 37 & & 2 & No & No & 0 & 0 & 0 & 0 & 0 & 0 \\
\hline 38 & & 1 & No & No & 0 & 0 & 0 & 0 & 0 & 0 \\
\hline
\end{tabular}

*Incontinence: 0 - never; 1 - rarely ( $<1 /$ month); 2 - sometimes ( $<1 /$ week, $\geq 1 /$ month $) ; 3$ - usually $(<1 /$ daily, $\geq 1 /$ week $) ; 4$ - always ( $\geq 1 /$ daily); $\mathrm{QOL}=$ quality of life; †QOL impairment: 0 - not at all; 1 - little; 2 - moderate; 3 - quite; 4 - a lot; $\neq$ Wexner score $=$ sum of scores of incontinence, need for pads and QOL impairment; range 0-20; 0 - perfect continence; 20 - total incontinence 


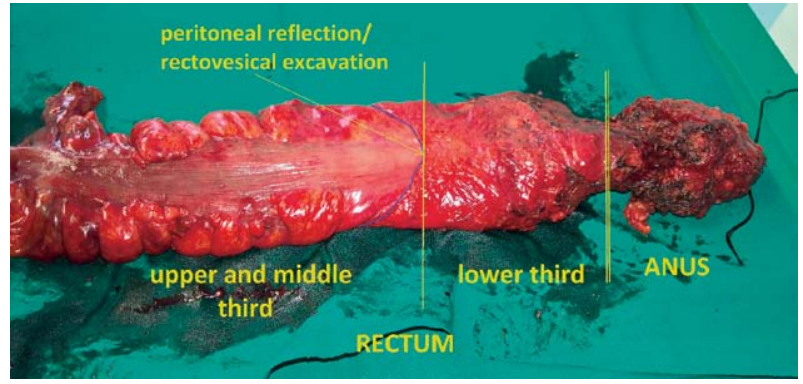

Fig. 1. Rectal specimen after total mesorectal excision - anterior view.

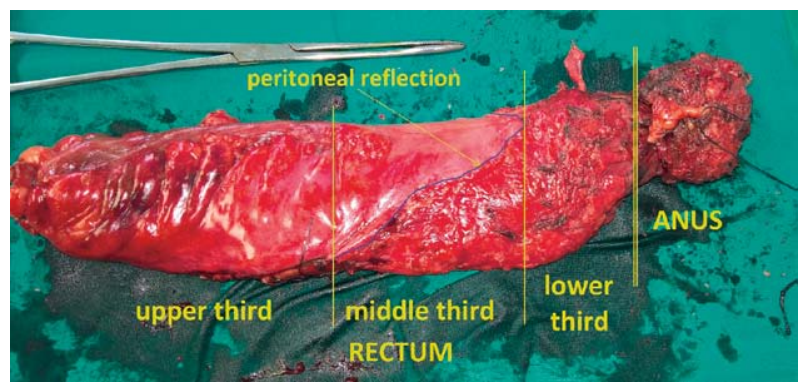

Fig. 2. Rectal specimen after total mesorectal excision - lateral view.

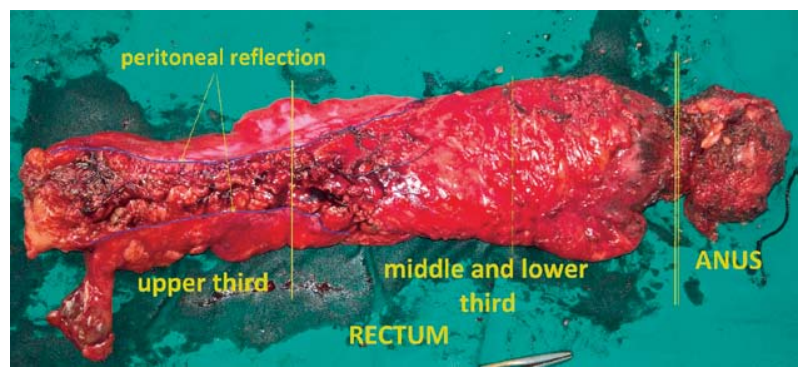

Fig. 3. Rectal specimen after total mesorectal excision - posterior view.

cluding ligation of the inferior mesenteric artery with or without preservation of the left colic artery. The splenic flexure was only mobilized when necessary. All colorectal anastomoses were created in end to end fashion using a circular mechanical stapler number.

Six months after surgery, the function of the anorectum was evaluated in all participants. The existence and severity of anterior resection syndrome was examined using a questionnaire that contained Wexner incontinence score and questions about the number of daily stools, urgency and discrimination. Wexner score takes into account five parameters that are scored on a scale from 0 to 4 : incontinence for solid and liquid stool, incontinence for gas, urgency, discrimination disorder, the need to wear pads and quality of life impairment (Table 1). Final score ranges from 0 to 20 , where 0 indicates perfect continence and 20 indicates total fecal incontinence.

In order to evaluate the impact of anastomosis level on anorectal functional disorder, we divided our $\mathrm{pa}$ tients into three groups according to their intraoperative finding of the colorectal anastomosis location, as follows: 1) high rectal anastomosis: colorectal anastomosis is located on the proximal third of the rectum (intraperitoneal part of the rectum, anterior and both lateral sides are covered with peritoneum) (Figs. 1-3); 2) mid rectal anastomosis: colorectal anastomosis is located on the middle third of the rectum (retroperitoneal part of the rectum, only anterior side of the rectum is covered with peritoneum) (Figs. 1-3); and 3) low rectal anastomosis: colorectal/coloanal anastomosis is located on the distal third of the rectum (extraperitoneal part of the rectum, below rectovesical/rectouterine excavation) (Figs. 1-3)

\section{Ethics}

The study was approved by the Sveti Duh University Hospital Ethics Committee. All patients included in the study provided their informed consent prior to inclusion. All procedures performed in studies involving human participants were in accordance with ethical standards of the institutional research committee and the 1964 Helsinki Declaration and its later amendments or comparable ethical standards.

\section{Statistics}

Relevant data collection was followed by data processing using appropriate statistical methods. Normality of numerical variable distribution was tested by Shapiro-Wilk test. Numerical variables with normal distribution were expressed as arithmetic mean \pm standard deviation (SD) and compared among the groups using one-way analysis of variance (ANOVA). Nonnormally distributed variables were expressed as median and interquartile range (IQR) and compared among the groups by use of Kruskal Wallis ANOVA. Categorical variables were expressed as ratio and percentage and compared between the groups using $\chi^{2}$-test. The increasing or decreasing trends in study parameters relative to the level of resection were tested 
Table 2. Characteristics of patients stratified according to the level of anastomosis

\begin{tabular}{|c|c|c|c|c|c|c|}
\hline & All patients & \begin{tabular}{|l}
$\begin{array}{l}\text { High } \\
\text { anastomosis }\end{array}$ \\
\end{tabular} & \begin{tabular}{|l} 
Mid \\
anastomosis
\end{tabular} & $\begin{array}{l}\text { Low } \\
\text { anastomosis }\end{array}$ & $\begin{array}{l}\mathrm{p} \text { for } \\
\text { differencet }\end{array}$ & $p$ for trend $\neq$ \\
\hline $\begin{array}{l}\text { Number of } \\
\text { participants }\end{array}$ & 38 & $13 / 38(34.2 \%)$ & $11 / 38(28.9 \%)$ & $14 / 38(36.8 \%)$ & - & - \\
\hline Age (years) & $67 \pm 8.9$ & $68.2 \pm 10$ & $69.6 \pm 8.6$ & $63.9 \pm 7.8$ & 0.237 & 0.305 \\
\hline Male & $25 / 38(65.8 \%)$ & 10/13 (76.9\%) & 6/11 (54.5\%) & 9/14 (64.3\%) & 0.510 & 0.501 \\
\hline Number of stools & 2 IQR (1-3) & 1 IQR (1-1) & 2 IQR (1-2.5) & 3 IQR (2-4) & $<0.001^{*}$ & $<0.001^{*}$ \\
\hline Urgency & $12 / 38(31.6 \%)$ & $1 / 13(7.7 \%)$ & $3 / 11(27.3 \%)$ & $8 / 14(57.1 \%))$ & $0.021^{*}$ & $0.006^{*}$ \\
\hline $\begin{array}{l}\text { Discrimination } \\
\text { disorder }\end{array}$ & $10 / 38(26.3 \%)$ & $0 / 13(0 \%)$ & $3 / 11(27.3 \%)$ & $7 / 14(50 \%)$ & $0.013^{*}$ & $0.003^{*}$ \\
\hline Solid incontinence & 0 IQR $(0-0)$ & $0 \mathrm{IQR}(0-0)$ & 0 IQR $(0-0)$ & 0 IQR $(0-1)$ & $0.044^{*}$ & $0.012^{*}$ \\
\hline Liquid incontinence & 0 IQR (0-1) & $0 \mathrm{IQR}(0-0)$ & 0 IQR $(0-0.5)$ & $1 \mathrm{IQR}(0-2)$ & $0.002^{*}$ & $<0.001^{*}$ \\
\hline Gas incontinence & 0 IQR $(0-1)$ & 0 IQR $(0-0)$ & 0 IQR $(0-1)$ & 2 IQR (1-2) & $<0.001^{*}$ & $<0.001^{*}$ \\
\hline Need for pads & 0 IQR $(0-0)$ & 0 IQR $(0-0)$ & 0 IQR $(0-0)$ & 0 IQR $(0-0.75)$ & 0.120 & $0.039^{*}$ \\
\hline QOL impairment & 1 IQR $(0-2)$ & $0 \mathrm{IQR}(0-0)$ & 0 IQR (0-1) & 0 IQR (1-2.75) & $<0.001^{*}$ & $<0.001^{*}$ \\
\hline Wexner score & 1 IQR (0-4) & 0 IQR $(0-0)$ & 0 IQR (0-3) & $5 \operatorname{IQR}(2.5-7)$ & $<0.001^{*}$ & $<0.001^{*}$ \\
\hline
\end{tabular}

*statistically significant at $\mathrm{p}<0.05$; QOL $=$ quality of life; †comparison if there is a statistically significant difference of tested parameters among different levels of anastomosis. One-way ANOVA $/ \chi^{2}$ test/Kruskal Wallis ANOVA tests were used; łcomparison if there is trend of increase or decrease of tested parameter with higher anastomosis level. Spearman correlation and $\chi^{2}$-test for trend were used.

by use of Spearman correlation and $\chi^{2}$-test for trend. The level of statistical significance was set at $\mathrm{p}<0.05$. Statistical analysis was performed by use of the MedCalc statistical software (MedCalc, Ostend, Belgium).

\section{Results}

Between January 2016 and December 2017, a total of 43 patients were registered for participation in the trial. During the study, five patients were excluded; three patients were lost during follow up or rejected participation in the study, one patient died during follow up, and one patient suffered from colorectal anastomosis dehiscence. Finally, 38 patients were analyzed, including 13/38 (34.2\%) patients with high rectal anastomosis, 11/38 (28.9\%) with mid rectal anastomosis and 14/38 (36.8\%) with low rectal anastomosis. Patient data are shown in Table 1 and characteristics of patients stratified according to the level of anastomosis in Table 2.

The mean patient age was $67 \pm 8.9$ years, with male predominance $(25 / 38 ; 65 \%)$. Patients with different levels of colorectal anastomosis were matched for age and sex. Patients with a lower level of anastomosis had a statistically significantly greater number of stools, higher urgency and discrimination impairment, more pronounced solid, liquid and gas incontinence, and greater need for diapers ( $\mathrm{p}<0.05$ all). Therefore, $\mathrm{pa}-$ tients with lower anastomosis had a statistically significant impairment of their quality of life and higher Wexner score ( $\mathrm{p}<0.001$ for both analyses) (Fig. 4).

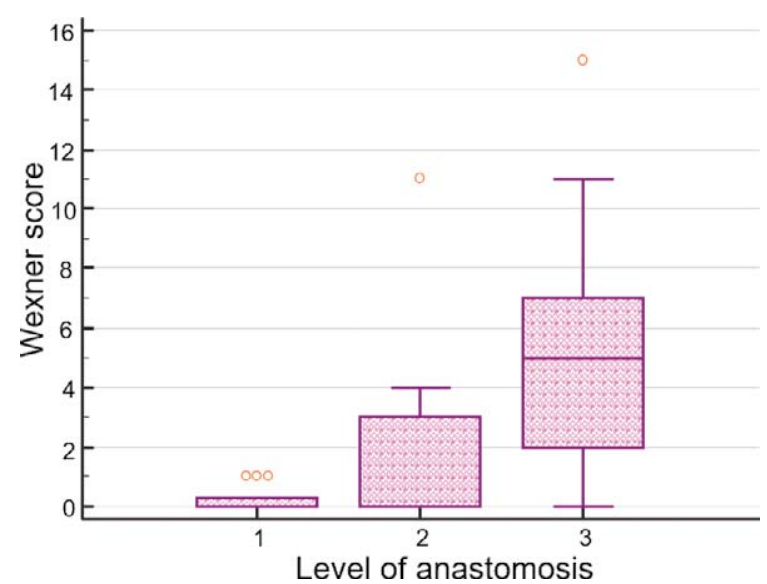

Fig. 4. Wexner score was statistically significantly different among 3 different levels of colorectal anastomosis (1 - high anastomosis; 2 - mid anastomosis;

3 - low anastomosis). 


\section{Discussion}

Analysis of study results revealed worsening of anorectum functioning in all parameters of the anterior resection syndrome with decrease in the anastomosis distance from the anal verge. Thus, almost all patients with anastomosis in the lower third of the rectum $(12 / 14)$ suffered from some form of fecal incontinence. In contrast, all patients with anastomosis in the proximal third of the rectum had nearly normal continence, and only three patients reported slightly impaired quality of life.

In the group of patients with anastomosis in the middle third of the rectum, results varied from normal to markedly impaired continence. Yet, taken together, their characteristics were more similar to those recorded in the group with high anastomosis. More than half of the patients with mid-third anastomosis had normal continence (6/11), while continence impairment was less pronounced in the remaining five patients when compared to the group with low anastomosis.

Our study results suggested reduced neorectal compliance to be the main pathophysiological factor for the development of postoperative anorectal function impairment. The lower rectum wall is known to be specifically capable of adapting by stretching to the increased intraluminal fecal volume, with consequential intrarectal pressure decrease, thus enabling temporary defecation delay. In our patients with anastomosis on the distal and middle third of the rectum, the distal half of the rectum had been completely or partially removed, resulting in urgency and fecal incontinence occurring more frequently in these patients. Accordingly, our study indicated saving the lower half of the rectum to be the key factor for preserving fecal continence.

Anal sphincter provides the mechanism that is indispensable for fecal continence. The question is whether and to what extent anal sphincter suffers damage during rectum resection. Currently, ever lower anastomoses with resection within internal sphincter in the form of partial or even total intersphincteric resection have been created. In case of correct indication and considering histologic type of the tumor and depth of invasion, it has been demonstrated that oncologic principles are not compromised with such ultralow rectum resections. This very fact encourages surgeons to perform these procedures. However, fecal continence is frequently seriously impaired in these patients. The surgeons unwilling to perform these procedures refer to these anastomoses as perineal stomata. On the other hand, many patients will prefer impaired continence with preserved natural position of the anus to colostomy. That is why it is crucial to talk to the patient preoperatively and warn them of all the potential complications, and then decide on the type of the procedure accordingly.

Besides preserving anatomical integrity, normal anal sphincter function also depends on preserving its innervation. Anal sphincter is controlled by the somatic and autonomic nervous systems via pudendal and hypogastric nerves. Hypogastric nerves are most susceptible to injury at two sites, i.e. during preparation at high ligation of the inferior mesenteric artery and on their passing across the sacral promontory to the presacral space.

Intersphincteric resection was not performed in our patients and they all had anatomical integrity of anal sphincter preserved, thus the possible anal sphincter dysfunction could have only been caused by innervation injury.

The extent to which fecal incontinence in our patients with low anastomoses was caused by reduced neorectum compliance or by possible nerve injury could not be defined with certainty. Additional manometric measurements of the anorectum postoperative function would certainly help resolve the issue. However, considering all the facts presented above, along with due intraoperative caution exercised to preserve the nerves, we still believe that reduced neorectum compliance was the main cause of fecal incontinence in our patients.

The ability to recognize the type of stool before defecation (stool discrimination) is of utmost importance for the quality of life. This ability is regulated by communication between the lower segment of the rectum and anus via intramural plexus. The increasing stool volume in the rectum with consequential rise in the intrarectal pressure leads to short-term relaxation of the upper part of internal anal sphincter innervated by the autonomic nervous system. This mechanism known as rectoanal inhibitory reflex (RAIR) ensures brief contact of the rectum content with the upper anus mucosa that contains sensory nerve endings ('sampling'), thus identifying the stool type. In our patients, the rate of stool discrimination impairment increased with lowering the level of anastomosis $(0 \%$, 
$27 \%$ and $50 \%$ for high, middle and low anastomosis, respectively). Therefore, we are inclined to believe that the lower the resection line on the rectum, the higher is the risk of cutting the intramural nerve fibers responsible for RAIR function.

The rectal resection line can be preoperatively estimated from colonoscopy finding of tumor distance from the anocutaneous border, and thus at least in part predict the risk of postoperative incontinence. According to our study, there is no risk of continence impairment in patients with tumors of the sigmoid and rectosigmoid junction scheduled to undergo high anterior resection with anastomosis in the proximal third of the rectum. On the other hand, in patients with tumors on the middle and distal third of the rectum scheduled for low anastomosis in the extraperitoneal segment of the rectum, some degree of fecal incontinence can be predicted with high probability.

\section{Conclusion}

Owing to advances in surgical technique and oncologic chemoradiotherapy, rectal cancers can currently be treated very successfully ${ }^{30}$. That is why the postoperative quality of life rather than just cure of the malignant disease has been increasingly considered by both the surgeons and patients. Unfortunately, there is no method yet to prevent postoperative continence impairment in patients with low anterior resection. Attempts at creating a J colonic pouch and other pouch modifications (e.g., transverse coloplasty pouch) failed to prove successful ${ }^{31-33}$.

For the time being, there is no alternative for the surgeon but to approach the patients with rectal tumors with due responsibility, which implies careful structure preparation and searching for appropriate total mesorectal excision plane with preservation of innervation, as for now it is the only way to minimize the risk of continence impairment.

\section{References}

1. Global Burden of Disease Cancer Collaboration, Fitzmaurice C, Allen C, Barber RM, Barregard L, Bhutta ZA, et al. Global, regional, and national cancer incidence, mortality, years of life lost, years lived with disability, and disability-adjusted life-years for 32 cancer groups, 1990 to 2015: a systematic analysis for the Global Burden of Disease Study. JAMA Oncol. 2017;3:524. doi: 10.1001/jamaoncol.2016.5688.
2. Jemal A, Ward EM, Johnson CJ, Cronin KA, Ma J, Ryerson B, et al. Annual report to the nation on the status of cancer, 19752014, featuring survival. J Natl Cancer Inst. 2017 Sep 1;109 (9):djx030. doi: 10.1093/jnci/djx030.

3. Siegel RL, Miller KD, Jemal A. Cancer statistics, 2018. CA Cancer J Clin. 2018; 68:7. doi: 10.3322/caac.21442

4. Tripkovic I, Strnad M, Polic-Vizintin M, Mulic R, Tripkovic I, Rakuljic M. Colorectal cancer in the Split-Dalmatia county. Acta Clin Croat. 2009;48:423-6.

5. Glynne-Jones R, Wyrwicz L, Tiret E, Brown G, Rödel C, Cervantes A, et al. Rectal cancer: ESMO Clinical Practice Guidelines for diagnosis, treatment and follow-up. Ann Oncol. 2018;29(Suppl 4):iv263. doi: 10.1093/annonc/mdy161

6. Ferlay J, Steliarova-Foucher E, Lortet-Tieulent J, Rosso S, Coebergh JW, Comber H, et al. Cancer incidence and mortality patterns in Europe: estimates for 40 countries in 2012. Eur J Cancer. 2013;49(6):1374-403. doi: 10.1016/j.ejca.2012.12.027.

7. Dixon CF. Anterior resection for malignant lesions of the upper part of the rectum and lower part of the sigmoid. Ann Surg. 1948;128:425-42.

8. Nelson H, Petrelli N, Carlin A, Couture J, Fleshman J, Guillem $\mathrm{J}$, et al. Guidelines 2000 for colon and rectal cancer surgery. J Natl Cancer Inst. 2001;93(8):583-596. doi: 10.1093/jnci/93.8.583

9. Bryant CL, Lunniss PJ, Knowles CH, Thaha MA, Chan CL. Anterior resection syndrome. Lancet Oncol. 2012;13:403-8. doi: 10.1016/S1470-2045(12)70236-X.

10. Jorge JM, Wexner SD. Etiology and management of fecal incontinence. Dis Colon Rectum. 1993;36(1):77-97. doi: 10.1007 /BF02050307

11. Salvioli B, Bharucha AE, Rath-Harvey D, Pemberton JH, Phillips SF. Rectal compliance, capacity, and rectoanal sensation in fecal incontinence. Am J Gastroenterol. 2001;96(7): 2158-2168. doi: 10.1111/j.1572-0241.2001.03954.x

12. Moszkowicz D, Alsaid B, Bessede T, Penna C, Nordlinger B, Benoît $\mathrm{G}$, et al. Where does pelvic nerve injury occur during rectal surgery for cancer?. Colorectal Dis. 2011;13(12):13261334. doi:10.1111/j.1463-1318.2010.02384.x

13. Koda K, Yasuda H, Hirano A, Kosugi C, Suzuki M, Yamazaki $\mathrm{M}$, et al. Evaluation of postoperative damage to anal sphincter/ levator ani muscles with three-dimensional vector manometry after sphincter-preserving operation for rectal cancer. J Am Coll Surg. 2009 Mar;208(3):362-7. doi: 10.1016/j.jamcollsurg.2008.10.035.

14. Hirano A, Koda K, Kosugi C, Yamazaki M, Yasuda H. Damage to anal sphincter/levator ani muscles caused by operative procedure in anal sphincter-preserving operation for rectal cancer. Am J Surg. 2011 Apr;201(4):508-13. doi: 10.1016/j.amjsurg.2009.12.016.

15. Jorge JMN, Habr-Gama A. Anatomy and embryology of the colon, rectum and anus. In: Wolff GG, et al., editors. The ASCRS Textbook of Colon and Rectal Surgery. New York, NY: Springer, 2007.

16. Nikolić V. Debelo crijevo. In: Nikolić V, Keros P, editors. Klinička anatomija abdomena. Zagreb: Naklada Ljevak; 2000. p. 129. (in Croatian) 
17. Gerdes B, Langer P, Kopp I, Bartsch D, Stinner B. Localization of the peritoneal reflection in the pelvis by endorectal ultrasound. Surg Endosc. 1998;12:1401-4.

18. Najarian MM, Belzer GE, Cogbill TH, Mathiason MA. Determination of the peritoneal reflection using intraoperative proctoscopy. Dis Colon Rectum. 2004;47:2080-5. doi: 10.1007/ s10350-004-0740-7.

19. Yun HR, Chun HK, Lee WS, Cho YB, Yun SH, Lee WY. Intra-operative measurement of surgical lengths of the rectum and the peritoneal reflection in Korean. J Korean Med Sci. 2008;23:999-1004. doi: 10.3346/jkms.2008.23.6.999.

20. Heald RJ, Moran BJ. Embryology and anatomy of the rectum. Semin Surg Oncol. 1998;15:66-71.

21. Law WL, Chu KW. Anterior resection for rectal cancer with mesorectal excision: a prospective evaluation of 622 patients. Ann Surg. 2004;240(2):260-268. doi: 10.1097/01.sla.000013 3185.23514 .32

22. Reynolds JV, Joyce WP, Dolan J, Sheahan K, Hyland JM. Pathological evidence in support of total mesorectal excision in the management of rectal cancer. Br J Surg. 1996;83(8):1112-5.

23. Komori K, Kanemitsu Y, Ishiguro S, Shimizu Y, Sano T, Ito S, et al. Adequate length of the surgical distal resection margin in rectal cancer: from the viewpoint of pathological findings. Am J Surg. 2012;204(4):474-80. doi: 10.1016/j.amjsurg.2011.11.009.

24. Morikawa E, Yasutomi M, Shindou K, Matsuda T, Mori N, Hida J, et al. Distribution of metastatic lymph nodes in colorectal cancer by the modified clearing method. Dis Colon Rectum. 1994;37(3):219-23.

25. Emmertsen KJ, Laurberg S; Rectal Cancer Function Study Group. Impact of bowel dysfunction on quality of life after sphincter-preserving resection for rectal cancer. Br J Surg. 2013 Sep;100(10):1377-87. doi: 10.1002/bjs.9223.

26. Floodeen H, Lindgren R, Hallböök O, Matthiessen P. Evaluation of long-term anorectal function after low anterior resection: a 5-year follow-up of a randomized multicenter trial.
Dis Colon Rectum. 2014 Oct;57(10):1162-8. doi: 10.1097/ DCR.0000000000000197.

27. Ihn MH, Kang SB, Kim DW, Oh HK, Lee SY, Hong SM. Risk factors for bowel dysfunction after sphincter-preserving rectal cancer surgery: a prospective study using the Memorial Sloan Kettering Cancer Center bowel function instrument. Dis Colon Rectum. 2014 Aug;57(8):958-66. doi: 10.1097/ DCR.0000000000000163.

28. Chapman SJ, Bolton WS, Corrigan N, Young N, Jayne DG. A cross-sectional review of reporting variation in postoperative bowel dysfunction after rectal cancer surgery. Dis Colon Rectum. 2017 Feb;60(2):240-7. doi: 10.1097/DCR.0000000000 000649 .

29. Scheer AS, Boushey RP, Liang S, Doucette S, O‘Connor AM, Moher D. The long-term gastrointestinal functional outcomes following curative anterior resection in adults with rectal cancer: a systematic review and meta-analysis. Dis Colon Rectum. 2011 Dec;54(12):1589-97. doi: 10.1097/DCR.0b013e3182214f11.

30. Sofic A, Vukobrat-Bijedic Z, Husic-Selimovic A, Sehovic N, Bulja D, Eminagic D, et al. Magnetic resonance imaging to evaluate neoadjuvant therapy effects on rectal carcinoma. Acta Clin Croat 2015;54:303-8.

31. Dulskas A, Miliauskas P, Tikuisis R, Escalante R, Samalavicius $\mathrm{NE}$. The functional results of radical rectal cancer surgery: review of the literature. Acta Chir Belg. 2016 Feb;116(1):1-10. doi: 10.1080/00015458.2015.1136482.

32. Mantyh CR, Hull TL, Fazio VW. Coloplasty in low colorectal anastomosis: manometric and functional comparison with straight and colonic J-pouch anastomosis. Dis Colon Rectum. 2001 Jan;44(1):37-42.

33. Tsunoda A, Kamiyama G, Narita K, Watanabe M, Nakao K, Kusano M. Prospective randomized trial for determination of optimum size of side limb in low anterior resection with sideto-end anastomosis for rectal carcinoma. Dis Colon Rectum. 2009Sep;52(9):1572-7.doi:10.1007/DCR.0b013e3181a909d4. 
Sažetak

\section{KORELACIJA IZMEĐU RAZINE KOLOREKTALNE ANASTOMOZE I FUNKCIJE ANOREKTUMA}

\section{B. Bakula, Ž. Rašić, D. Jurčić, M. Lucijanić i F. Rašić}

Anteriorna resekcija rektuma je standardni operacijski zahvat kod liječenja karcinoma rektuma i distalnog dijela sigmoidnog kolona. U mnogim slučajevima anteriorne resekcije poslijeoperacijski se pojavljuje određena razina fekalne inkontinencije. Cilj naše studije bio je istražiti utjecaj visine kolorektalne anastomoze na funkcijski poremećaj anorektuma. Svi ispitanici su podvrgnuti standardnoj otvorenoj ili laparoskopskoj anteriornoj resekciji. Šest mjeseci nakon operacije funkcija anorektuma je evaluirana. Ukupno je analizirano 38 bolesnika, tj. 13/38 (34,2\%) s visokom kolorektalnom anastomozom, $11 / 38(28,9 \%)$ sa srednjom kolorektalnom anastomozom i 14/38 (36,8\%) s niskom kolorektalnom anastomozom. Bolesnici s niže postavljenom anastomozom imali su statistički značajno veći broj stolica, češce su imali urgenciju i poremećaj diskriminacije, kao i jače izraženu krutu, tekuću i inkontinenciju plinova, češće su trebali pelene ( $<<0,05$ za sve navedene analize). Sukladno tome, bolesnici s niže postavljenom anastomozom imali su statistički značajno jače narušenu kvalitetu života i viši Wexnerov zbir ( $\mathrm{p}<0,001$ za obje analize). Mišljenja smo da je smanjeni kapacitet neorektuma glavni patofiziološki čimbenik za razvoj poslijeoperacijskog funkcijskog poremećaja anorektuma.

Ključne riječi: Anteriorna resekcija; Karcinom rektuma; Wexnerov bodovni sustav; Funkcija anorektuma 